\title{
Celebrity Politicians as Health-Promoting Role Models in the Media: the Cases of Vladimir Putin, Donald Trump, and Benjamin Netanyahu
}

\author{
Narmina Abdulaev ${ }^{1,2} \cdot$ Baruch Shomron ${ }^{1}$ (D) \\ Accepted: 29 September 2020 / Published online: 12 October 2020 \\ (C) Springer Science+Business Media, LLC, part of Springer Nature 2020
}

\begin{abstract}
In recent years, scholars have increasingly revealed the importance of celebrities in society, among them celebrity politicians. These celebrities not only influence political attitudes but also serve as role models for many individuals. Yet, little is known regarding what types of role models' politicians serve as in the context of health. To fill this gap, we examined three influential contemporary political leaders: Vladimir Putin, Donald Trump and Benjamin Netanyahu, and the type of mediated role models each possibly comprise in the context of healthy living. By conducting a qualitative content analysis, we analyzed 90 articles from 2018 to 2019 from two leading newspapers in each of the three politician's countries, namely Russia, the USA, and Israel as well as the respective politician's Facebook pages. Our findings point to three types of potential role models' as political leaders: a health-promoting model (Putin), a hybrid model (Trump), and a model of non-existence (Netanyahu), as the literature points to mediated role models influencing individuals' beliefs and behaviors. This study contributes to the understanding of mediated types of role models' politicians potentially serve as in the context of health vital to people's personal health.
\end{abstract}

Keywords Celebrities $\cdot$ Celebrity politicians $\cdot$ Role models $\cdot$ Social learning $\cdot$ Public health

$\underline{\text { Narmina Abdulaev and Baruch Shomron contributed equally to this article. }}$

Baruch Shomron

baruchshomron@gmail.com

Narmina Abdulaev

narmina@post.bgu.ac.il

1 The Faculty of Humanities and Social Sciences, Department of Communications Studies, Ben-Gurion University of the Negev, P.O. Box 653, 84105 Beer-Sheva, Israel

2 Department of Hebrew and Comparative Literature, University of Haifa, Haifa, Israel 


\section{Introduction}

"The president [Vladimir Putin] never welcomed smoking, he is a supporter of a healthy lifestyle (...) There are only a few colleagues who smoke, there are fewer of them than fingers on the hand, in general this is now very unpopular, which is encouraging," said a Kremlin spokesman (https://www.kp.ru/online/news/3621031/)

Celebrities are not a new phenomenon, and scholars have identified many individuals from the past three centuries as celebrities. Indeed, celebrity culture has been playing a significant role in society for generations. The rise of celebrities, and prominent among them celebrity politicians has gone hand in hand with the rise of mass media and new communication technologies. Thus, celebrity culture is in constant development and change both influencing and being influenced by society. The literature has shown that celebrities can have an important impact on their audiences. This impact ranges from encouraging people to consume specific commercial products- to persuading people to adopt different behaviors and attitudes. Three of the most well-known political leaders currently in the national and international arena are Russian President Vladimir Putin, US President Donald Trump, and Israeli Prime Minister Benjamin Netanyahu. We propose that their celebrity status turns these politicians into potential role models that could play an important role in their respective societies. In this cross-national study conducted on both traditional media and social media, we focus on the context of promoting health and examine the role models these celebrity politicians potentially offer through their media depictions, possibly affecting the health of many individuals exposed to them. Though this study does not include the audience's input, the study points to the potential role model's celebrity politicians serve as in the context of healthy living. As yet, little is known regarding what types of role models' politicians serve as in the context of health. We set out to fill this gap by examining these three influential contemporary political leaders. Indeed, we do not wish to examine how politicians utilize the media for their own needs (e.g., their image), but rather focus on the types of role models these politicians potentially serve as in the context of health.

\section{Role Models and the Media}

A role model is a person who serves as an example to other people by (a) showing them how to do the things they desire, (b) revealing to them what is attainable, and (c) sharing with them what is socially desirable (Morgenroth et al. 2015). This psychological phenomenon termed "social modeling" constitutes one of the two ways of social learning: "people learn through the direct experience of rewarding and punishing effects of actions, and through the power of social modeling" (Bandura 2003: 77). There are many advantages to learning through role models, including the ability to be exposed to possibilities that exist outside a person's immediate environment (Morgenroth et al. 2015), as well as the opportunity to learn new things without "costly or injurious consequences" (Bandura 2003: 77).

While any person can serve as a role model to any other person, for example, a teacher to his or her students or a parent to their children; role models can also appear through the mediated forms of media content (Bandura 2003; Jackson and Vares 2015). Furthermore, the media can amplify the influences of a single role model as the media content can be received by many individuals simultaneously (Bandura 2003). Of equal importance, the media further enriches the function of the role model by exposing people to content created in faraway 
geographical locations, depicting people with whom the individual may not otherwise associate in their daily lives, and presenting goals that might not be popular or known in an individual's surrounding (Morgenroth et al. 2015). The mediated celebrity role model has an important function in society particularly as "a social sign, carrying cultural meanings and ideological values, which express the intimacies of individual personality, inviting desire and identification; an emblem of national celebrity, founded on the body, fashion, and personal style" (Gledhil 1991: xiii).

It is important to realize that mediated role models can appear in any media content, such as characters in a television series, interviewees in news programs, or as subjects portrayed by media coverage (Author and other 2020; Hesmondhalgh 2018; Jackson and Vares 2015).

Clearly then, the importance of role models in the media is apparent: by amplifying the influences of role models, the media presents many individuals with the social models attainable and desirable for them, influencing their personal advancement in life (Bandura 2003). This influence consists of what individuals perceive they can or should do (Morgenroth et al. 2015), affecting the opportunities enabled to each individual in society (Shomron and Schejter 2020; Hesmondhalgh 2018). For example, "bad" role models in the media can negatively influence the opportunities of teenagers (Jackson and Vares 2015), and the lack of role models can negatively influence the opportunities of individuals to advance professionally (Shomron and Schejter 2020).

It is worth noting that according to the commonality effect of the "intergroup identity model", the influence of a role model is potentially greater among those who share high levels of commonality with the role model (Gaertner and Dovidio 2011; Gómez et al. 2013). This commonality relates to identity characteristics such as ethnicity, gender, or nationality and can either reduce or amplify influences of potential role models as "norms expressed by ingroup members are more likely to be internalized" (Gómez et al. 2013: 427).

Role-modeling is naturally incorporated in structures of celebrity and leadership. This incorporation derives from a two-way approach in which celebrities wish to influence the public and the public wish to emulate celebrities. This stems from celebrities being perceived as representing the desired social and economic goals in society (Brockington 2009; Street 2004; Wheeler 2013). Indeed, some scholars have criticized the role of celebrities in society suggesting they preserve existing social structures and service the elites (Brockington 2009; Wheeler 2013). The attractiveness of celebrities and their persuasive nature emanates in part from their developed-for-marketing persona which individuals can intimately relate with (Marshall et al. 2015). Thus, it is not the merits of the messaging, but rather the public's connection with the celebrity's marketed persona which can influence the support and prospective role-modeling (Dow 2017).

\section{Celebrities, Politicians and the Media}

In recent decades, an in-depth discussion of celebrity has been of increasing interest. The first studies began in the 1950s (Mills 1956; Stever 2018) while the emphasis on becoming a separate field of research began only in the twenty-first century marked by the founding of the journal Celebrity Studies in 2010. However, celebrities are not a new phenomenon, and scholars have identified many individuals from the past three centuries as celebrities. Indeed, for generations, celebrity culture has been playing a significant role in society (Morgan 2011; Wheeler 2013). The rise of celebrities and prominent among them celebrity politicians has 
gone hand in hand with the rise of mass media and new communication technologies (Wheeler 2013), from engraved portraits and the nineteenth century penny papers to television and film (Morgan 2011) and presumedly micro-bloggers on social media today. For centuries, politicians have habitually taken advantage of the media platforms available in their time for fame and political promotion (Wheeler 2013). Thus, celebrity culture is in constant development and change both influencing and being influenced by society. The term celebrity was first defined by Boorstin as "a person who is known for his well-knownness" (Boorstin 1962: 57). It has been suggested that celebrities serve as another layer in society and act as mediators between elites and corporations and the consumers (Alberoni 1972). Although quite a few conditions are required in making an ordinary person famous, visual media play the leading role perpetuating it (Alberoni 1972; Boorstin 1962). Ever since the development of photographic image reproduction technologies in the nineteenth century, image representations have become widespread, and play a vital role in attracting the audiences' attention (Boorstin 1962). While the early works of Boorstin and Alberoni have drawn criticism for ideological bias, more recent scholars have emphasized the interdisciplinary nature of celebrity studies, pointing to a three-pointed relationship between the media industry, the individual celebrity, and the consumer-audience (Turner 2004; Williamson 2016). Indeed, both Turner and Williamson point to capitalism as the main driving force behind the creation of celebrities, linking fame to commercial profiting.

Celebrities tend to function as prominent role models influencing consumption habits, body image attitudes, lifestyles and habits, political opinions, and more (Hollander 2010; Lawler 2010; Redmond 2019; Stever 2018). Regarding health, celebrities have been known to promote both positive and negative behaviors. This is evident in some instances when different celebrities have promoted the consumption of fast foods and sugary drinks, while in other instances, celebrities have called attention to health awareness and physical activities (Caulfield 2016; Hoffman et al. 2017).

For instance, American actress Jane Fonda has advocated for nutrition as well as healthy living and has significantly affected many individuals who have adopted her lifestyle (MacNeill 1998; Mansfield 2011). Another example is Hollywood actress Angelina Jolie who underwent preventative breast cancer surgery and simultaneously utilized the opportunity to raise awareness of the disease and influence other women to be tested, and when needed, undergo preventive surgery (Dean 2016; Tetteh 2019).

With the rise of worldwide populism in the political arena, politicians have become even more prominent and influential in society (Marshall 2020; Mishra and Mishra 2014; Wright 2020). That is, politicians tend to be some of the most widely known celebrities in society, as Postman (1987) explained in the late 1980s: "Political figures may show up anywhere, at any time, doing anything, without being thought odd, presumptuous, or in any way out of place. Which is to say, they have become assimilated into general television culture as celebrities (Postman 1987: 135). This rise in prominence and influence then derives partially from the development of new media technologies. More than ever, politicians are promoting themselves as individual brands beyond party and policy. Media abundance combined with capitalist tendencies, enable politicians to transform their persona into a commodity, and market themselves on different media platforms. The salient portrayal of politicians in the media contributes to their celebrity standing, turning them into potential role models (Loader et al. 2016; Marcus 2019; Marshall 2020; Street 2004). Yet, to be considered a celebrity politician, an individual must abide by three basic conditions. First, the individual must be a politician or be highly engaged in public policy (Marsh et al. 2010). Second, the individual 
must heavily utilize an approach of "show business" and "popular culture" as a means for political gain, viewing politics as a "spectacle that is to be performed to an audience, not of citizens, but of spectators“ (Street 2012: 350). And third, the individual must be successful in gaining high levels of fame and personal recognition (Marsh et al. 2010; Marshall 2020). Thus, not all politicians rise to the level of celebrity, as they might not meet the three conditions. When politicians do not become celebrities, the probability of their serving as role models considerably diminishes due to their anonymity or lack of a marketed persona. Many scholars have tried to characterize the phenomenon of celebrity politicians by creating typologies (Loader et al. 2016; Marsh et al. 2010; Street 2004; West and Orman 2003). For example, Marsh et al. (2010) suggest five categories: "celebrity advocate," "celebrity activist/endorser," "celebrity politician," "politician celebrity," and "politician who uses others' celebrity" (Marsh et al. 2010: 327). In this study we focus on two "politician celebrities"-Vladimir Putin and Benjamin Netanyahu - both of whom represent politicians that can be recognized as popular celebrities, and one "celebrity politician"-Donald Trump - who was a celebrity before becoming a politician.

Politicians tend to utilize the media for political advancement including the promotion of their own public image and policies (McLaughlin and Macafee 2019; Tamul et al. 2020; Vos and Van Aelst 2018; Wells et al. 2020). As such, it is possible that politicians' health-related images could be strategically cultivated by the politicians' political needs. However, in this study, we neither focus on these political needs nor strategies. Rather, focus on the types of role models these politicians potentially serve as in the context of health. Indeed, the purpose of this study is to examine how celebrity politicians might influence individual's health, rather than how politicians utilize the media for their own needs. Yet, the reader should be mindful that the relationship between these two objectives-self-promotion and influencing individuals - is highly interconnected (Bennett et al. 2019; Kousser and Tranter 2018).

However, some wider peripheral context is needed regarding the political health agendas of the three politicians chosen for the study. Since his rise to power in 1999, President Vladimir Putin has been a strong advocate for state sponsored health care as part of the promotion of wider social policies following the fall of the Soviet Union. Accordingly, during his 20-year tenure, he has led many health reforms with the objective of providing better health services to the Russian people. Yet, the Russian health system suffers from structural weaknesses and underfunding, and the implementation of these health reforms has not always been considered successful (Brooke and Gans-Morse 2016; Sokhey 2020). Thus, examining health through self-promotion and political communication can be argued that the Russian President regularly caters to voters through the advocation of strengthening public health as a tool to raise his political popularity (Sokhey 2020). In stark contrast, President Donald Trump tends to view health as the responsibility of the individual and not the state, assenting to mainstream American Republican ideology. For example, during his time in office he has advocated for the termination of the Affordable Care Act which expanded the government's role in supplying healthcare. Yet, he has also advocated for the reduction of medication costs as their high prices are perceived by him as a market failure (Hatcher 2019; Levitt 2020). Thus, examining health through self-promotion and political communication can be argued that the American President regularly caters to republican voters by advocating reducing the government's role in the provision of health (Beland et al. 2019). In contrast, healthcare in Israel is provided mainly by the state through universal health coverage. The public health system which ranks high among OECD countries is not considered a controversial issue in Israeli politics. And most political discussions regarding the public health system focus on budgeting issues. 
Accordingly, Prime Minister Benjamin Netanyahu regularly advocates for strengthening the public health system taking credit for its success, while political opponents mainly criticize him for underfunding the system (Central Bureau of Statistics 2019; Devi 2019; Filut and Zarchia 2019). Thus, examining health through self-promotion and political communication can be argued that the Israeli Prime Minister regularly caters to Israeli voters through advocating strengthening the public health system as a tool to raise his political popularity (Devi 2019).

Additionally, it should be noted that the three politicians chosen for this study share similar conservative political leanings in their respective countries. As politician's political ideology plays an important part shaping their approach to health issues (Shen and LaBouff 2016), it could also shape the specific health role models they might choose to constitute. For example, it has been suggested that conservative politicians are "less inclined to support redistribution [of resources]" due to their meritocratic approach which stems from their own personal advantages and privilege (Berggren et al. 2017: 79). Thus, as the three politicians chosen as cases for this study, all share the same conservative political leaning, they might be less inclined to serve as role models and promote health as they could consider health a matter of the individual's personal agency. Furthermore, as all three politicians chosen in this study are male, white, and wealthy, thus, enjoying different advantages and privilege, this could strengthen their meritocratic approach even more (Shen and LaBouff 2016).

When discussing political communication and self-promotion, most of the politicians' mediated activities have occurred in traditional media such as television and newspapers, yet with the rise of social media, many politicians identified its potential and have tried to utilize it as well for their own self-promotion (Bruns and Moon 2018; Ceccobelli 2018; McLaughlin and Macafee 2019; Samuel-Azran et al. 2018; Tamul et al. 2020; Wells et al. 2020). Facebook, as one of the leading social media platforms, has been heavily utilized by politicians, especially during elections, for this purpose (Edgerly et al. 2016; Samuel-Azran et al. 2018; Talshir 2015). Politicians' depictions and messaging on social media serve as a loyal representation of the politicians' point of view without the mediation of reporters and traditional media practices (Enli and Skogerbo 2013). Furthermore, politicians tend to share on social media more of the behind-the-scenes moments including intimate moments that rarely appear in the traditional media (Enli and Skogerbo 2013). Of course, the reader should be aware that most social media accounts are not operated by the politician himself, but rather by the politician's media team. For example, even Donald Trump — who is known for his Twitter messaging - employs a social media director who has full control over the president's Twitter account, and regularly "ghost" tweets (Chute 2019). Yet, for the point of this study, we do not find it beneficial to distinguish between content that originates from the politician himself and content that originates from the politician's media team, since we are focusing on the politician's media portrayal as it is seen by the public, who cannot usually identify the difference between those two sources.

Vladimir Putin, Donald Trump, and Benjamin Netanyahu each have a complex relationship with the media which corresponds to their respective type of political power. While all three have received high levels of negative coverage from their local and national media outlets, they have each reacted differently according to the political power at their disposal. Under Putin's considerable political power, free speech and free press have been restricted, and many media outlets subjected to direct Kremlin control (Skillen 2016). Netanyahu, on the other hand, has less political power, and enjoys the relatively new privately funded pro-Netanyahu "Israel Hayom" newspaper (Dahan and Bentham 2017), the most popular newspaper in the country 
(Katz 2019). Moreover, Netanyahu has recently been indicted for offering media organizations regulatory benefits in exchange for positive media coverage (Liebermann and Tal 2020). As viewed in the USA, the media is relatively divided between Democrat-leaning media and Republican-leaning media, accordingly either critical or promoting Trump. This power sharing situation in the media represents the power sharing situation in US politics. Thus, the president is limited to criticizing the "fake" media, encouraging his followers to avoid their consumption, and bypassing them on social media (Enli 2017).

\section{Media and Health}

Information and communication technologies (ICTs) can play a vital role regarding an individual's health. They range from interactive social media discussions influencing individuals' medical perceptions (Peng et al. 2019), to vital information delivered through mass media outlets (Gibson et al. 2019), and health-related beliefs and behaviors portrayed on popular television series (Baglia and Foster 2015). The link between politician role models and health is of special significance. For instance, political hypocrisy which refers to a dissonance between what a politician politically advocates and personally practices can substantially affect public perceptions and behavior (Bhatti et al. 2013; Von-Sikorski and Herbst 2020). Since politicians serve in leadership roles responsible for the public's wellbeing, this could have dire consequences to public health, as political advocation for health policies could be undermined by political hypocrisy practiced by the same politicians. Covid-19 which is a highly contagious respiratory disease serves as a prime example to the importance of politician's role-modeling in the context of health. As there are no known treatments to the disease, public health has depended mainly on the public's adherence to safety regulations put in place by political leadership (World Health Organization 2020). However, as some politicians have failed to abide by their own safety regulations, it has been suggested they were endangering the public's health due to negative role modeling and political hypocrisy (Young and Bluth 2020). Thus, though the connection between politician role models and health is significant, little is known regarding the types of role models' celebrity politicians serve as in the context of health. In order to fill this gap, we propose the following research questions:

- RQ1: Do celebrity politicians appear in the mass media as health-promoting role-models?

- RQ2: Do these celebrity politicians role models differ between countries?

- RQ3: What types of health-related role models do celebrity politicians promote themselves on their social media Facebook pages?

\section{Methods}

In this study, we conducted a qualitative content analysis of 90 newspaper articles in order to understand if celebrity politicians were depicted as health-promoting role-models. The crossnational analysis focused on three contemporary known heads of state: Russian President Vladimir Putin, American President Donald Trump, and Israeli Prime Minister Benjamin Netanyahu. All three politicians chosen for this study enjoy a high profile in their respective countries and frequently appear in their national media (Dahan and Bentham 2017; Katz 2017; Kazun and Semykina 2019; Street 2019; Wright 2020). The politicians were chosen through 
convenience sampling (Ritchie et al. 2013) in consideration with the language skills of the authors, and with the goal of analyzing the most well-known political leaders in office. In the study, we analyzed two national daily newspapers in each of the three countries: Russia, the USA, and Israel, choosing the most popular national tabloid together with the most popular national quality newspaper (Appendix Table 1). The inclusion of both types of newspapers was done in order to allow for a more comprehensive understanding of the national newspaper coverage, as well as to allow for a comparison between both types of newspapers.

The newspaper articles sample method consisted of a non-systematic quota sampling (Ritchie et al. 2013). In this method we predefined a quota of 15 relevant articles per newspaper $(2 \times 15 \times 3=90)$. Thus, analyzing 30 articles $(2 \times 15)$ from each country. A relevant article was defined as a newspaper article that appeared in one of the chosen newspapers between January 2018 and November 2019 and discussed the personal healthrelated habits of the respective head of state. In order to encompass this topic, we comprised a list of notable health-related habits:

1 Positive nutritional habits (DeSalvo et al. 2016).

2 Receiving medical treatment or physical examinations (Zaman 2018).

3 Participating in physical workouts and sport activities (Piercy et al. 2018).

4 Avoiding non-healthy habits such as smoking or excessive alcohol drinking (Noble et al. 2015).

5 Participating in activities promoting good mental health such as spending time in nature (Barton and Pretty 2010).

In order to optimize the search for current articles, we used each of the newspapers search engines by inserting health-related keywords such as: health, workout, diet, sick, food, eat, doctor, gym, fast food, lifestyle, sport, muscle, alcohol, and hospital.

A grounded theory thematic analysis was then conducted on the relevant newspaper articles focusing on the literal and visual content of each article (Ritchie et al. 2013). The analysis was conducted in three languages by the authors who are bilingual, both having fluent language proficiency in two languages, (Hebrew and Russian/English and Hebrew).

Additionally, the study included a qualitative content analysis (Ritchie et al. 2013) of the three politician's Facebook pages. This analysis included all Facebook posts discussing the personal habits of the heads of state in the aforementioned five topics. The sample included all Facebook posts appearing between October 2018 to December 2019. All three leaders maintain active and popular Facebook pages (Appendix Table 2).

\section{Findings}

We found that the three celebrity politicians appeared in the media in three unique ways, each representing a different and distinct model. President Vladimir Putin represented a "healthpromoting model" by regularly partaking in sports activities and leading a healthy lifestyle. President Donald Trump represented a "hybrid model" consisting of both positive and negative health-related habits. And Prime Minister Benjamin Netanyahu represented a "model of non-existence" in which his media portrayal refrained from including any references to his personal health habits. 


\section{The Health-Promoting Model}

Both Russian newspapers depicted Putin as a health-promoting role model. The main emphasis of Putin's health was comprised of sports activities. The Russian president appeared regularly in sport activities in which he personally took part. For instance, both newspapers reported Putin playing hockey, as well as participating in martial arts matches and skiing. Specifically, during a hockey game Putin played, he humorously remarked: "“I will strive to ensure that you [the other team] look decent [in the match]."' The article later recounted this did not happen: "[Putin] did not keep his promise" the article read"[since] at the beginning of the match he [immediately] shot the puck into the net..." (KP, 23 September, 2019); "Putin is known for his passion for various sports. The President, in particular, plays hockey, skis, and engages in judo and swimming" (IZ, 10 October, 2019); "Putin is known for his passion playing various sports, in particular, [he] plays hockey, and engages in judo and swimming. Likewise on February 13, the Russian leader went skiing in Sochi with Lukashenko" (IZ, 12 March, 2019); "[after] the Russian president spoke with the [Russian] national teams in freestyle wrestling, boxing and judo, he changed into their apparel and trained with the athletes" (IZ, 10 October, 2019). The newspapers also tended to recount Putin's past sports activities: "II learned to skate with a chair, by setting the chair in front of me,' [Putin] recalled" (KP, 12 May, 2019); "The first sport I practiced was boxing, [and I remember] my nose was broken [by my opponent]" (IZ, 10 October, 2019).

Putin was also portrayed as a nature enthusiast and enjoying the outdoors. These activities are known to promote relaxation and advance positive mental health (Barton and Pretty 2010): "“I went hiking two days ago" the president said, "I walked almost nine kilometers through the mountains and everything still hurts," (KP, 07 October, 2019); "the president [Putin] has repeatedly said that Russia is a vast, beautiful and rich country... [and therefore] Putin's task as head of state is to lead by example and to popularize places [in nature] that "most citizens don't know exist"' (IZ, 13 October, 2019).

When it comes to Putin's health, the media has portrayed him as a healthy person, though avoided from substantiating this statement with medical information such as medical examination results (e.g., blood pressure or cholesterol). A case in point, when Putin was asked by reporters about his health, and he responded that "everything was in order with his health, [and this] was due to his regular engagement in sport activities. 'Like everyone else, there may be some flu or something else in the offseason, but today everything is in order,"' $(I Z, 20$ December, 2018).

Both newspapers negated discussing the Russian president's eating habits in detail, as well as his personal habits regarding the consumption of alcohol or smoking.

From these themes and examples, we conclude that Putin is portrayed as a healthpromoting role model.

\section{The Hybrid Model}

The American newspapers depicted Donald Trump simultaneously in both a positive and negative way. On the positive side, the president was portrayed by both newspapers as an avid golf player: "I played a very fast round of golf yesterday" (USA Today, 03 September, 2019); "Mr. Trump, pointedly uninvited, engaged in what by now is a familiar weekend routine. He sent a series of angry tweets aimed at some political adversaries, then left the White House to 
play a round of golf at his resort in Virginia" (NYT, 03 September, 2019). It should be noted that even though the last example is written as criticism of Trump, it does not hinder the positive portrayal in the health-related context of participating in sport activities. Playing golf is considered a "moderate intensity physical activity" associated with "physical health benefits that include improved cardiovascular, respiratory and metabolic profiles, and improved wellness" (Murray et al. 2017: 12). However, the reader should be aware of the social-cultural context of this sport. Golf is associated with wealth and power, and routinely utilized by the social elite for networking and promoting financial and political interests (Agarwal et al. 2016). Thus, one could speculate that Trump plays golf partially for political reasons such as networking with other politicians and businessmen in addition to the health benefits. Furthermore, as Trump himself owns many golf resorts, it is possible that his habitual playing at his resorts serves as a promotional tool for these resorts.

Additionally, both newspapers reported that the President was considered healthy by his doctors and medical examination results. By way of example: "Trump is in 'excellent health' doctor says after exam" (NYT, 12 January, 2018); "Trump is in 'very good health' following his annual physical, his doctor says" (NYT, 08 February, 2019); "President Trump is in 'excellent health' and his first medical checkup since taking office 'went exceptionally well,' a White House doctor said Friday” (USA Today, 12 January, 2018); “A White House doctor pronounced President Trump medically fit to serve as commander-in-chief on Tuesday - and added that he easily passed a voluntary cognitive assessment designed to test his mental reflexes" (USA Today, 16 January, 2018). It is also notable that Trump is known to be a teetotaler (Restuccia 2018) and did not appear in either newspapers consuming alcohol.

In contrast, both newspapers also tended to speculate about Trump's health, insinuating he was not physically healthy or mentally capable. For example: "Mental health professionals: Trump's rash Syria move looked like a 'hypomanic episode" (USA Today, 13 November, 2019); "Trump — who once described his exercise regimen as "I walk, I this, I that" — has long faced questions about his health" (USA Today, 14 February, 2019); "Cardiologists not associated with the White House said Wednesday that President Trump's physical exam revealed serious heart concerns, including very high levels of so-called bad cholesterol, which raises the risk that Mr. Trump could have a heart attack while in office" (NYT, 17 January, 2018); "Mr. Trump has long faced questions about his mental stability and his fitness for office" (NYT, 16 July, 2018). Furthermore, the president was portrayed by both newspapers as a non-healthy eater who consumed large amounts of fast food: "Piles of burgers and fish sandwiches from McDonald's, Wendy's and Burger King, still in their boxes and wrappers, were served on trays in the candlelit dining room. Tubs of dipping sauces were stacked in silver gravy boats. On another table, heat lamps kept French fries and Domino's pizzas warm... The substitution didn't seem to bother Mr. Trump, and perhaps even delighted him. 'I like it all,' he told reporters before the players arrived. 'It's all good stuff. Great American food'” (NYT, 15 January, 2019).

\section{A Model of Non-Existence}

Both Israeli newspapers ignored Prime Minister Benjamin Netanyahu's health habits. They both refrained from discussing his eating habits, medical state, or workout regime. The only time the Israeli media mentioned this topic was indirectly and incidentally by discussing corruption charges brought against him. Those charges which included deception and breach of trust (known in Israel as the criminal "Case 1000") allege the Prime Minister received 
$195,000 \$$ worth of cigars and alcohol. This charge, which was consistently covered by the media, insinuates that Netanyahu is both a heavy smoker and heavy drinker: "Netanyahu allegedly received benefits (cigars, champagne, and jewelry) from businessmen for 20 years" (Israel Hayom, 08 October, 2019); "Netanyahu seemingly does not deny that he and his wife received for many years cigars, champagne bottles and jewelry from two businessmen" (Israel Hayom, 16 February, 2018); "It is suspected that [Mr.] Milchan gifted the prime minister and his wife cigar boxes, champagne boxes and other products, by request" (Haaretz, 28 February, 2019); "the estimated value of cigars Netanyahu received is between 200-300 thousand [57,000\$-86,000\$]" (Haaretz, 23 January, 2018).

Though many articles discussed the corruption charges brought against Netanyahu regarding the cigar gifts, and thus indirectly addressing his health habits, as no other references were made regarding his health-related habits, we conclude that Netanyahu's model of portrayal is non-existence.

\section{The Accompanying Visual Content: Discrepancy or Match}

Two compelling themes arose when analyzing the images that accompanied the newspaper articles. The first theme was a complete match between the written word and the visual image. This was the case with Putin. For example, in an article discussing Putin practicing Judo, the accompanying photograph showed the president in a Judo uniform working out on the mats (KP, 14 February, 2019). While a match between the photographs and the words can strengthen the messaging, a discrepancy can undermine this messaging (e.g., that the politician is in fact engaging in a healthy lifestyle). Thus, the second theme included a recurring discrepancy between the story and the photographs. This was the case with both Trump and Netanyahu. For example, in an article describing Trump playing golf, the accompanying photograph showed the president walking down an airstair (NYT, 01 September, 2018); and in an article describing Netanyahu receiving large amounts of cigars, the accompanying photograph showed the prime minister giving a speech earlier that month (Haaretz, 28 February, 2019).

\section{The Three Celeb-Politician's Social Media Health-Related Portrayal}

After analyzing the types of role models, each of the three politicians was depicted in the traditional media; we turn to understand how these politicians portrayed themselves on their social media Facebook accounts, respectively. To be clear, we first wish to remind the reader that politicians employ media teams to help operate their social media accounts, and thus some, if not all the content on these accounts, could originate from these media teams rather than from the politician himself.

Our analysis found that President Putin's social media messaging in the context of health habits was in accordance with his portrayal by the traditional media. Putin shared through his Facebook page videos and pictures of himself participating in diverse sport activities such as boxing, hiking and horse riding (Images 1 and 2). However, Putin refrained from sharing content on Facebook without regard to other health aspects such as: nutritional habits, medical information and treatment, unhealthy habits such as smoking or excessive alcohol drinking. This was in accordance with his portrayal by the traditional media. 


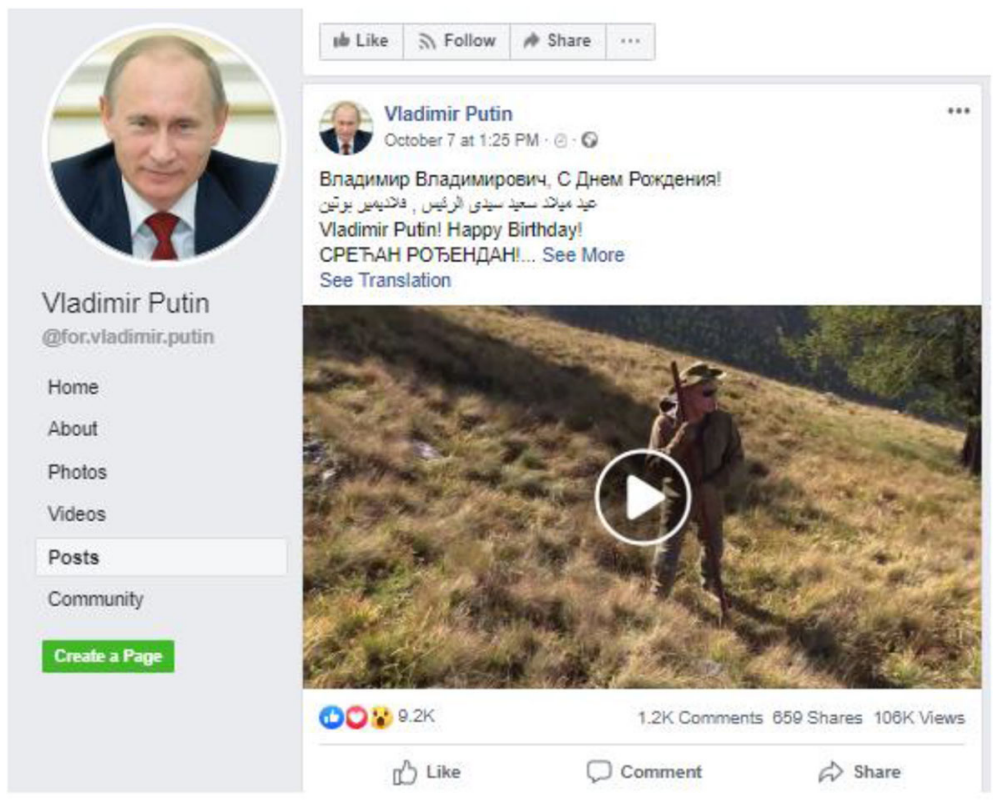

Image 1 President Vladimir Putin shared on Facebook a video of himself hiking (07.10.19)

Though President Trump was portrayed by the traditional media in both a positive and negative light (the hybrid model), Trump negated sharing any information regarding his health on his Facebook page. There was only one exception to this practice: on November 27, 2019, Trump shared on his Facebook page a doctored photo of his head on the muscular body of "Rocky Balboa" the fictional boxer played by Sylvester Stallone (Image 3). Though the president refrained from adding an explanation to this picture, newspapers suggested the

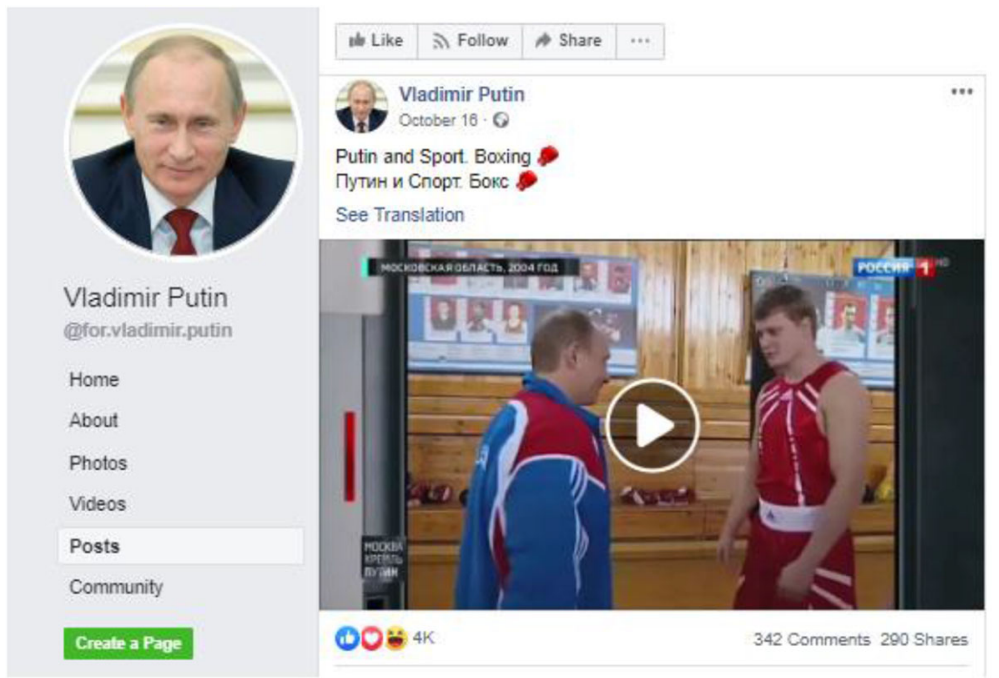

Image 2 President Vladimir Putin shared on Facebook a video of himself boxing (16.10.19) 
Image 3 President Donald Trump shared on Facebook a doctored picture of his muscular self (27.11.19)

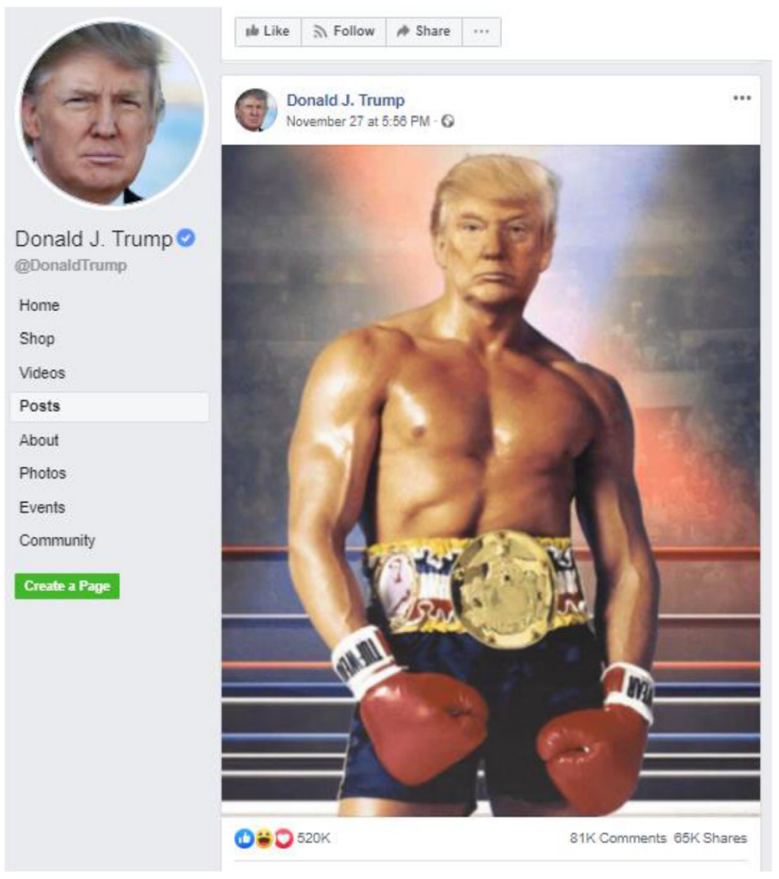

picture was a political message conveying a "powerful image of himself” (Crowley 2019) or to "declare himself a heavyweight champion in politics" (Dorman 2019).

In accordance with Prime Minister's Benjamin Netanyahu's portrayal in the traditional media (the model of non-existence), Netanyahu refrained from sharing any content regarding his health habits on his Facebook page. The only exception to this practice was that Netanyahu regularly (approximately once every 2 months) shared photos in which he can be seen alone or with his family spending time in nature (Images 4 and 5).

\section{Discussion and Conclusions}

We propose that the politicians at the center of this work are celebrities, and as such, can serve as role models for individuals possibly affecting people's health (Dean 2016; MacNeill 1998; Mansfield 2011; Tetteh 2019). As little is known regarding the types of role models' politicians serve in the context of health, we set out in this study to fill this gap by examining three leading and influential political leaders: Vladimir Putin, Donald Trump, and Benjamin Netanyahu. The analysis presented here suggests the existence of three unique types of healthrelated role models that celebrity politicians portray in the media. President Vladimir Putin represented a health-promoting model, President Donald Trump represented a hybrid model, and Prime Minister Benjamin Netanyahu represented a model of non-existence.

Various explanations exist for the different models in which the three heads of state appeared. It has been suggested in the literature that Putin's media depictions act as a personification of the Russian nation and state (Tempest 2016). This personification includes the physical appearance (e.g., masculinity and strength) and the health of the leader, which 


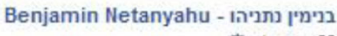

6. - ᄂา 22

עם המשפחה בבית הכנסת העתיק בכפר נחום ובשמורת גמלא שברמת הגולן.

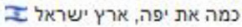

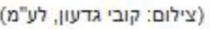
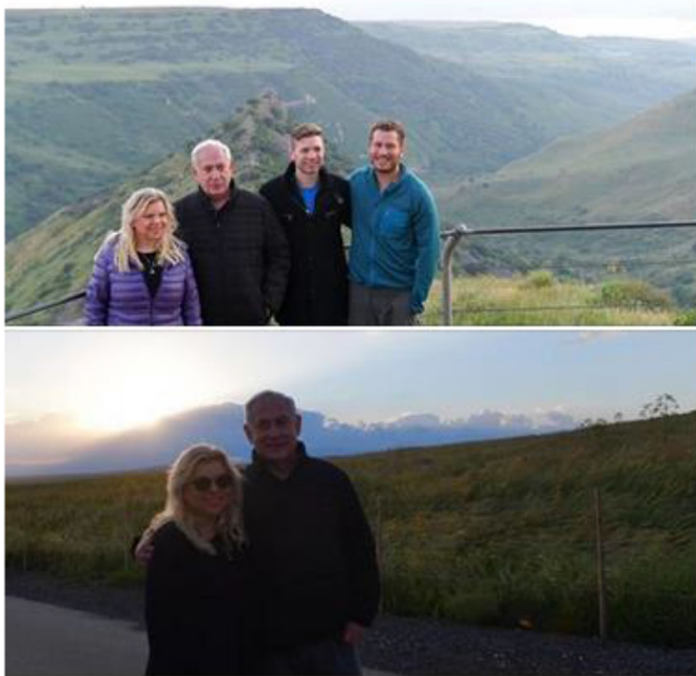

Dogres 410 תามก 952

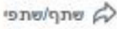

$18 K \div 00$

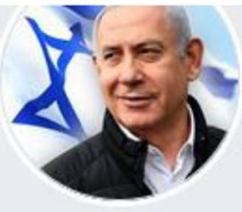

Benjamin Netanyahu

- בנימין נתניהו -

Netanyahu@

דף הבית

אודות

תמונות

סרטונים

רה"מ באינטים

רה"מ בטוויטר

Q0019

אירועים

קהילה

Image 4 Prime Minister Benjamin Netanyahu shared on Facebook pictures spending time in nature (22.04.19)
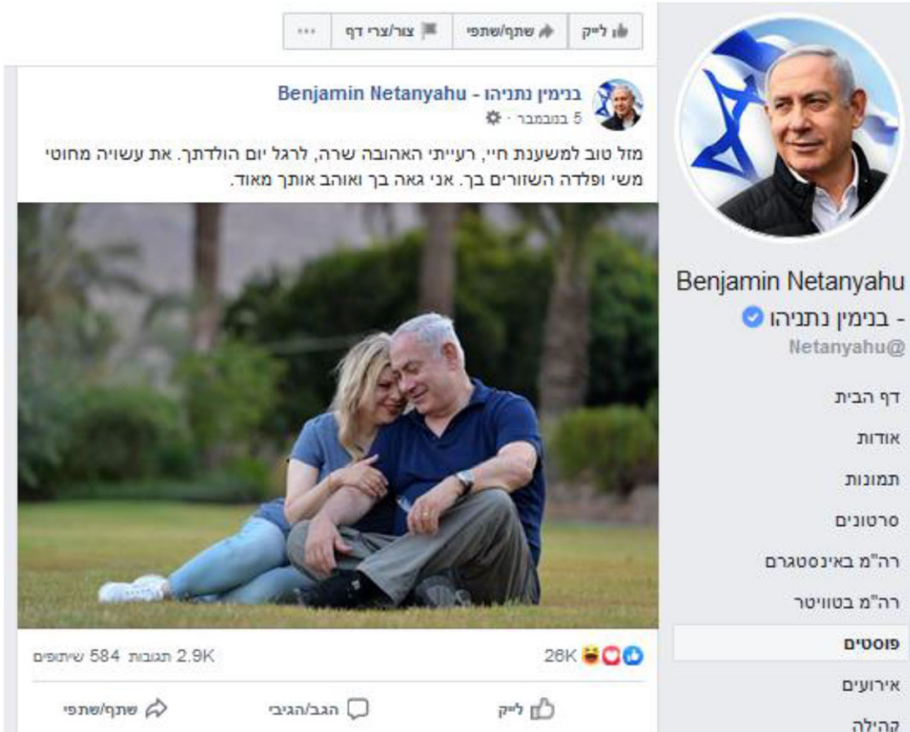

Benjamin Netanyahu

-

Netanyahu@

דף הבית

אוד

תמונות

סרטונים

רה"מ באינטינים

רה"מ בטוויטר

Dיolg

אירועים

קהילה

Image 5 Prime Minister Benjamin Netanyahu shared on Facebook a picture in nature with his wife (05.11.19)

\section{黑 Springer}


represents the country's health and strength (Tempest 2016). Additionally, the positive portrayal the two newspapers provided Putin, could derive from the unique relationship that exists between the Russian media and the Russian government. This relationship is characterized as a recruited media that serves the administration and especially its head (Hinck et al. 2018; Langdon and Tismaneanu 2020).

The analysis of Trump's portrayal suggests that the president's health is a political matter in the USA. By this explanation, the mixed depictions represent a political sentiment which either supports Trump as president or doubts his ability to hold the job (Lischka 2019; Vorberg and Zeitler 2019). We further hypothesize that the uniformity in Trump's media depiction by both American newspapers represents the highly debated political discourse surrounding Trump's legitimacy as president (Lawrence and Boydstun 2017; Vorberg and Zeitler 2019). As such, both newspapers regardless of their political leaning or newspaper type, serve as platforms for political messaging for and against the president in accordance with the freedom of the press (Lawrence and Boydstun 2017).

Our study points to a model of non-existence that characterizes prime minister Netanyahu. Though Netanyahu is not the personification of the Israeli state as explained in the case of Russia, one could expect the Israeli press to express mixed health-related sentiments as in the case of America, as similar conditions exists in Israel (e.g., free press and political opposers and supporters). A possible explanation to this non-existence could be the Israeli media's long standing non-formal tradition to avoid discussing heads of state health issues (Dinor-Lavie and Karniel 2009; Kitel 2006). Though many Israeli prime ministers suffered serious health issues throughout their years in office, the Israeli media systematically refrained from reporting upon them, even though they were fully aware of them (Dinor-Lavie and Karniel 2009; Kitel 2006). With this in mind, we consider it beneficial to have included a leading Israeli politician in this study as this sheds light on celebrity politicians who do not serve as health-related role models as well as add nuance to understanding the Israeli case. Additionally, Netanyahu's model of nonexistence could serve as negative role-modeling in which political leaders conceal their weaknesses from their supporters, thus encouraging people to hide their own weaknesses. This could be due to Israel's militarized socialization which frames citizens as soldiers and politicians as officers (Levy and Sasson-Levy 2008) who are wary of displaying weakness to their subordinates.

Although health is perceived in diverse cultures in a similar way, its social and cultural meanings differ greatly. In Russia, health may be understood in relation to the cult of the new Soviet Man and the idealized Soviet bodies (Novitskaya 2017). Moreover, Putin's healthy portrayal stands in contrast to his predecessor Yeltsin, who was known for his excessive drinking and unhealthy lifestyle (Rowley 2019; Treisman 2011). In Israel, sport and health might have a totally different social resonance. Since before the establishment of the Israeli state, central-left political parties promoted health and specifically fitness to distinguish themselves from the "exiled Jew" (Falk 2017). Netanyahu's avoidance from portraying healthy habits might derive from his heading the central-right political party "Likud" that opposes the central-left's ideology. In the USA, there is a strong awareness of health-related issues constantly fueled by the ongoing debate between Republicans and Democrats over health reform policies (Forgey and Diamond 2020). Moreover, Trump's health-related behavior should also be seen as a reaction to the previous administration as evidenced in Trump's criticism of the Affordable Care Act passed during the Obama administration (Forgey and Diamond 2020).

By analyzing the celebrity politician's social media accounts on Facebook, we catch a possible glimpse of the types of role models by which these politicians wish to be portrayed in 
society. Our research shows that the politician's depiction on Facebook mostly resembles their portrayal by the traditional media. This finding points to a possible linkage between the content on both platforms: traditional media and social media, that might be a result of each country's unique culture (Dinor-Lavie and Karniel 2009; Kitel 2006), or a close association between the leader and the media (Hinck et al. 2018; Langdon and Tismaneanu 2020). We suggest future research analyze the audience reactions on Facebook in order to find evidence and further illuminate whether people consider politicians to be role models regarding health.

Although this study provides a better understanding of the types of role models' politicians potentially serve as in the context of health, it does not include input from the audiences. Furthermore, it should be noted that the possible effects of these three politician role models might differ greatly between audiences as a result of the commonality effect of the "intergroup identity model" (Gaertner and Dovidio 2011; Gómez et al. 2013). For example, would the main audiences affected by each politician come from each of the three politicians' political parties respectively? Or perhaps as all three politicians chosen for this study were males, the effects would be stronger with the male audience? Thus, future studies that examine the effects of mediated role models on audiences should consider the characteristics of the potential role models such as their gender, ethnicity, and political beliefs.

Notwithstanding the lack of audience inclusion in this study, we hypothesize the possible effects each of the three models could have on individuals. These hypotheses stem from the vast literature regarding the connection between mediated role models and audience effects (e.g., Dean 2016; Hoffman et al. 2017; MacNeill 1998; Mansfield 2011; Postman 1987; Tetteh 2019), and we suggest that further studies should look to confirm or refute these hypotheses. We hypothesize that the health-promoting model could contribute more than the other models to the health of individuals. Additionally, we hypothesize that the hybrid model could have mixed results both positive and negative on the health of individuals. And we hypothesize that the model of non-existence could have little or no influence on the health of individuals. As this is not an effects study, we cannot verify that any of our three politicians influence any individual's health at all. However, we deem these hypotheses plausible based upon the known connection cited in the literature above. Furthermore, as the components affecting health are complex and there are many of them (Dumuid et al. 2018), we cannot discuss an actual effect size between media depictions and the state of health in each of the countries, and thus, even if these mediated role model affected individuals' health, further research would have to measure the effects size.

An interesting question relates to a possible shift in the images of these politicians over time. Indeed, during the duration of this study, we found that the images of all three politicians were static; however, we recommend further research evaluate these images over larger amounts of time, especially as all three politicians in this study have been in the public sphere for many years. A prime example for future research in this context can be a comparison between the role-modeling of different politicians during the Covid-19 pandemic. During this pandemic, the public's health has relied mainly on the public's compliance with safety regulations put in place by political leadership (World Health Organization 2020). This compliance can easily be affected by the politician's role-modeling, due to political hypocrisy, social learning and imitation, as well as the commonality effect and ideology.

As yet, little is known regarding what types of role models' politicians serve as in the context of health, we set out in this study to fill this gap by examining three leading and influential political leaders: Vladimir Putin, Donald Trump, and Benjamin Netanyahu. In the study, we identified three unique models in which the heads of state were depicted in the 
media. We hypothesized how each of these models would affect the health of citizens in each of the three countries. And we offered possible explanations for the depictions of each head of state's model. This study contributes to understanding the mediated types of role models' politicians potentially serve as in the context of health.

\section{Compliance with Ethical Standards}

- The authors declare that they have no conflict of interest. And no relationship exists between the researchers and the politicians appearing in the study.

- The research did not include human participants; thus, no consent was needed. This is an observational study focusing on mass media content and public Facebook profiles of heads of state.

\section{Appendix}

Table 1 Heads of state and national newspapers

\begin{tabular}{|c|c|c|c|c|c|}
\hline Country & Head of state & Tabloid newspaper & Readership & $\begin{array}{l}\text { Quality } \\
\text { newspaper }\end{array}$ & Readership \\
\hline USA & $\begin{array}{l}\text { Donald } \\
\text { Trump }\end{array}$ & USA today (English) & $\begin{array}{l}\text { Ranked 1st. } 1.6 \\
\text { million circulated in } \\
2018 \text { (CMR 2019) }\end{array}$ & $\begin{array}{l}\text { The New York } \\
\text { Times } \\
\text { (English) }\end{array}$ & $\begin{array}{l}\text { Ranked 3rd. } \\
\quad 484,000 \text { in } 2018 \\
\text { (CMR 2019) }\end{array}$ \\
\hline Russia & $\begin{array}{l}\text { Vladimir } \\
\text { Putin }\end{array}$ & $\begin{array}{l}\text { Komsomolskaya } \\
\text { Pravda (Russian) }\end{array}$ & $\begin{array}{l}\text { Rank 20/1000 from } \\
\text { ru-net }\end{array}$ & $\begin{array}{l}\text { Izvestia } \\
\quad \text { (Russian) }\end{array}$ & $\begin{array}{l}\text { Rank } 23 / 1000 \text { from } \\
\text { ru-net }\end{array}$ \\
\hline Israel & $\begin{array}{l}\text { Benjamin } \\
\text { Netanyahu }\end{array}$ & $\begin{array}{l}\text { Israel Hayom } \\
\quad \text { (Hebrew) }\end{array}$ & $\begin{array}{l}\text { Ranked 1st. } 30.6 \% \\
\text { in } 2019 \text { (Katz } \\
\text { 2019) }\end{array}$ & $\begin{array}{l}\text { Haaretz } \\
\text { (Hebrew) }\end{array}$ & $\begin{array}{l}\text { Ranked 3rd. } 4.7 \% \\
\text { in } 2019 \\
\text { (Katz 2019) }\end{array}$ \\
\hline
\end{tabular}

Table 2 Heads of state Facebook pages

\begin{tabular}{|c|c|c|c|}
\hline Head of state & $\begin{array}{l}\text { Total number } \\
\text { of likes }\end{array}$ & $\begin{array}{l}\text { Total number } \\
\text { of followers }\end{array}$ & Link \\
\hline Donald Trump & 24 million & 26 million & https://www.facebook.com/DonaldTrump/ \\
\hline Vladimir Putin & 2 million & 2 million & https://www.facebook.com/for.vladimir.putin/ \\
\hline Benjamin Netanyahu & 2.4 million & 2.4 million & https://www.facebook.com/Netanyahu/ \\
\hline
\end{tabular}

\section{References}

Agarwal, S., Qian, W., Reeb, D. M., \& Sing, T. F. (2016). Playing the boys game: golf buddies and board diversity. The American Economic Review, 106(5), 272-276.

Alberoni, F. (1972). The powerless 'Elite': theory and sociological research on the phenomenon of the stars. In D. McQuail (Ed.), Sociology of mass communications: Selected readings (pp. 75-98). Middlesex: Penguin Books.

Baglia, J., \& Foster, E. (2015). Mad men as health communication: Health-related themes in the hit AMC television series. Health Communication, 30(1), 50-60.

Bandura, A. (2003). Social cognitive theory for personal and social change by enabling media. In A. Singhal, M. J. Cody, E. M. Rogers, \& M. Sabido (Eds.), Entertainment-education and social change (pp. 75-96). London: Routledge.

Barton, J., \& Pretty, J. (2010). What is the best dose of nature and green exercise for improving mental health? A multi-study analysis. Environmental Science \& Technology, 44(10), 3947-3955. 
Beland, D., Rocco, P., \& Waddan, A. (2019). Policy feedback and the politics of the Affordable Care Act. Policy Studies Journal, 47(2), 395-422.

Bennett, A., Malone, C., Cheatham, K., \& Saligram, N. (2019). The impact of perceptions of politician brand warmth and competence on voting intentions. The Journal of Product and Brand Management, 28(2), 256273.

Berggren, N., Jordahl, H., \& Poutvaara, P. (2017). The right look: conservative politicians look better and voters reward it. Journal of Public Economics, 146, 79-86.

Bhatti, Y., Hansen, K. M., \& Olsen, A. L. (2013). Political hypocrisy: the effect of political scandals on candidate evaluations. Acta Politica, 48(4), 408-428.

Boorstin, D. (1962). The image or what happened to the American dream. New York: Atheneum.

Brockington, D. (2009). Celebrity and the environment: fame, wealth and power in conservation. London \& New York: Zed Books.

Brooke, H. S. G., \& Gans-Morse, J. (2016). Putin's crackdown on mortality: rethinking legal nihilism and state capacity in light of Russia's surprising public health campaigns. Problems of Post-Communism, 63(1), 1-15.

Bruns, A., \& Moon, B. (2018). Social media in Australian Federal elections: comparing the 2013 and 2016 campaigns. Journalism and Mass Communication Quarterly, 95(2), 425-448.

Caulfield, T. (2016). From Kim Kardashian to Dr. Oz: the future relevance of popular culture to our health and health policy. Ottawa Law Review, 47(2), 371-389.

Ceccobelli, D. (2018). Not every day is election day: a comparative analysis of eighteen election campaigns on Facebook. Journal of Information Technology \& Politics, 15(2), 122-141.

Central Bureau of Statistics (2019). New OECD Report - Health at a Glance 2019: Health spending expected to outpace GDP growth in the next 15 years. https://www.cbs.gov.il/he/mediarelease/DocLib/2019/337 /05 19 337e.pdf. Accessed 7 Oct 2020.

Chute, $\bar{N}$. (2019). He writes Trump's tweets and has been with Trump's campaign since day one. USA Today. https:/www.usatoday.com/story/news/politics/2019/06/18/donald-trump-twitter-president-white-house-danscavino-golf-course-covfefe/1495205001/. Accessed 7 Oct 2020.

Cision Media Research. (2019). T4op 10 U.S. Daily Newspapers. Media Blog. https://www.cision.com/us/2019 /01/top-ten-us-daily-newspapers/. Accessed 7 Oct 2020.

Crowley, J. (2019). Trump tweeted a photo of his face on Rocky Balboa and the Internet erupted. Newsweek https://www.newsweek.com/trump-rocky-balboa-tweet-responses-sylvester-stallone-1474482. Accessed 7 Oct 2020.

Dahan, M., \& Bentham, M. (2017). The ripple effects of a partisan, free newspaper: Israel Hayom as disruptive media actor. Studies in Communication Sciences, 1, 99-106.

Dean, M. (2016). Celebrity health announcements and online health information seeking: an analysis of Angelina Jolie's preventative health decision. Health Communication, 31(6), 752-761.

DeSalvo, K. B., Olson, R., \& Casavale, K. O. (2016). Dietary guidelines for Americans. Jama, 31(5), 457-458.

Devi, S. (2019). World report health in Israel and the OPT in the lead-up to elections. The Lancet, 393, $973-974$.

Dinor-Lavie, A., \& Karniel, Y. (2009). The right to know against the need for consolation - journalists and doctors between professionalism and patriotism: coverage of Prime Minister Ariel Sharon's illness in the press in Israel. Media Frames: Israeli Media Journal, 3, 83-135.

Dorman, S. (2019). Trump tweets photo of himself as 'Rocky' ahead of more impeachment hearings. Fox News. https://www.foxnews.com/politics/donald-trump-rocky-photo-boxer. Accessed 7 Oct 2020.

Dow, B. J. (2017). Taking Trump seriously: persona and presidential politics in 2016. Women's Studies in Communication, 40(2), 136-139.

Dumuid, D., Maher, C., Lewis, L. K., Stanford, T. E., Martín Fernández, J. A., Ratcliffe, J., Katzmarzyk, P. T., Barreira, T. V., Chaput, J. P., Fogelholm, M., Hu, G., Maia, J., Sarmiento, O. L., Standage, M., Tremblay, M. S., Tudor-Locke, C., \& Olds, T. (2018). Human development index, children's health-related quality of life and movement behaviors: a compositional data analysis. Quality of Life Research, 27, 1473-1482. https://doi.org/10.1007/s11136-018-1791-x.

Edgerly, S., Thorson, K., Bighash, L., \& Hannah, M. (2016). Posting about politics: media as resources for political expression on Facebook. Journal of Information Technology \& Politics, 13(2), 108-125.

Enli, G. (2017). Twitter as arena for the authentic outsider: exploring the social media campaigns of Trump and Clinton in the 2016 US presidential election. European Journal of Communication, 32(1), 50-61.

Enli, G. S., \& Skogerbo, E. (2013). Personalized campaigns in party-centred politics. Information, Communication \& Society, 16(5), 757-774.

Falk, R. (2017). Zionism and the Biology of Jews. Springer.

Filut, A. \& Zarchia, Z. (2019). To your health, but where will the funding come from. Calcalist. https://www. calcalist.co.il/local/articles/0,7340,L-3758379,00.html. Accessed 7 Oct 2020. 
Forgey, Q., \& Diamond, D. (2020). Trump attacks Blumberg on healthcare with misleading claim. Politico. https:/www.politico.com/news/2020/01/13/donald-trump-michael-bloomberg-health-care-advertisement098099. Accessed 7 Oct 2020.

Gaertner, S. L., \& Dovidio, J. F. (2011). Reducing intergroup bias: the common ingroup identity model. In P. Van Lange, A. Kruglanski, \& E. T. Higgins (Eds.), Handbook of theories of social psychology (pp. 439457). London: SAGE.

Gibson, L. A., Siegel, L., Kranzler, E., Volinsky, A., O’Donnell, M. B., Williams, S., et al. (2019). Combining crowd-sourcing and automated content methods to improve estimates of overall media coverage: theme mentions in E-cigarette and other tobacco coverage. Journal of Health Communication, 24(12), 889-899.

Gledhil, C. (1991). Stardom: industry of desire. London: Routledge.

Gómez, Á., Dovidio, J. F., Gaertner, S. L., Fernández, S., \& Vázquez, A. (2013). Responses to endorsement of commonality by ingroup and outgroup members: the roles of group representation and threat. Personality and Social Psychology Bulletin, 39(4), 419-431.

Hatcher, W. (2019). President Trump and health care: a content analysis of misleading statements. Journal of Public Health. https://doi.org/10.1093/pubmed/fdz176.

Hesmondhalgh, D. (2018). Television, Quality of Life and the Value of Culture. In A Future for Public Service Television, edited by D. Freedman and Goblot, (pp. 151-156). London: Goldsmiths Press.

Hinck, R. S., Kluver, R., \& Cooley, S. (2018). Russia re-envisions the world: strategic narratives in Russian broadcast and news media during 2015. Russian Journal of Communication, 10(1), 21-37.

Hoffman, S. J., Mansoor, Y., Natt, N., Sritharan, L., Belluz, J., Caulfield, T., Freedhoff, Y., Lavis, J. N., \& Sharma, A. M. (2017). Celebrities' impact on health-related knowledge, attitudes, behaviors, and status outcomes: protocol for a systematic review, meta-analysis, and meta-regression analysis. Systematic Reviews, 6(1), 13.

Hollander, P. (2010). Why the celebrity cult? Society, 47(5), 388-391.

Jackson, S., \& Vares, T. (2015). Too many bad role models for us girls': girls, female pop celebrities and 'sexualization. Sexualities, 18(4), 480-498.

Katz, Y. (2017). How Netanyahu's new media policy is influencing Israeli, American and global politics. International Relations, 5(8), 501-510.

Katz, A. (2019). Heaven now? a leap in exposure to newspapers, Maariv and Haaretz recover Ice. http://www. ice.co.il/media/news/article/766481. Accessed 7 Oct 2020.

Kazun, A., \& Semykina, K. (2019). Presidential elections 2018: the struggle of Putin and Navalny for a media agenda. Problems of Post-Communism, 1-12. https://doi.org/10.1080/10758216.2019.1685893.

Kitel, S. (2006). Journalistic and medical dilemmas in public health coverage. In Y. Rachamim (Ed.), Difficult but stable, the media, doctors and leader illness (pp. 49-51). Tel-Aviv: Haim Herzog Institute for Communication, Society and Politics at Tel Aviv University.

Kousser, T., \& Tranter, B. (2018). The influence of political leaders on climate change attitudes. Global Environmental Change, 50, 100-109.

Langdon, K. C., \& Tismaneanu, V. (2020). Putin's totalitarian democracy: Ideology. myth and violence in the twenty-first century. New York: Palgrave Macmillan.

Lawler, P. A. (2010). Celebrity studies today. Society, 47(5), 419-423.

Lawrence, R. G., \& Boydstun, A. E. (2017). What we should really be asking about media attention to Trump. Political Communication, 34(1), 150-153.

Levitt, L. (2020). Trump vs Biden on health care. JAMA Health Forum, 1(9). https://doi.org/10.1001 /jamahealthforum.2020.1110

Levy, G., \& Sasson-Levy, O. (2008). Militarized socialization, military service, and class reproduction: the experiences of Israeli soldiers. Sociological Perspectives, 51(2), 349-374.

Liebermann, O., \& Tal, A. (2020). Israel's Netanyahu indicted in corruption cases, hours before Mideast peace plan announced. CNN. https://edition.cnn.com/2020/01/28/middleeast/israel-netanyahu-withdrawsimmunity-request-intl/index.html. Accessed 7 Oct 2020.

Lischka, J. A. (2019). A badge of honor? How The New York Times discredits president Trump's fake news accusations. Journalism Studies, 20(2), 287-304.

Loader, B. D., Vromen, A., \& Xenos, M. A. (2016). Performing for the young networked citizen? Celebrity politics, social networking and the political engagement of young people. Media, Culture and Society, 38(3), 400-419.

MacNeill, M. (1998). Sex, lies and videotape: the political and cultural economics of celebrity fitness videos. In G. Rail (Ed.), Sport and postmodern times (pp. 143-163). New York: SUNY.

Mansfield, L. (2011). 'Sexercise': working out heterosexuality in Jane Fonda's fitness books. Leisure Studies, 30(2), 237-255.

Marcus, S. (2019). The drama of celebrity. Princeton \& Oxford: Princeton University Press.

Marsh, D., Hart, P. T., \& Tindall, K. (2010). Celebrity politics: the politics of late modernity? Political Studies Review, 8(3), 322-340. 
Marshall, P. D. (2020). Celebrity, politics, and new media: an essay on the implications of pandemic fame and persona. International journal of politics, culture, and society, 33(1), 89-104.

Marshall, P. D., Moore, C., \& Barbour, K. (2015). Persona as method: exploring celebrity and the public self through persona studies. Celebrity Studies, 6(3), 288-305.

McLaughlin, B., \& Macafee, T. (2019). Becoming a Presidential candidate: social media following and politician identification. Mass Communication and Society, 22(5), 584-603. https://doi.org/10.1080 /15205436.2019.1614196.

Mills, W. (1956). The power elite. Oxford: Oxford University.

Mishra, A. A., \& Mishra, A. (2014). National vs. local celebrity endorsement and politics. International Journal of Politics, Culture, and Society, 27(4), 409-425.

Morgan, S. (2011). Celebrity: academic 'pseudo-event'or a useful concept for historians? Cultural and Social History, 8(1), 95-114.

Morgenroth, T., Ryan, M. K., \& Peters, K. (2015). The motivational theory of role modeling: how role models influence role aspirants' goals. Review of General Psychology, 19(4), 465-483.

Murray, A. D., Daines, L., Archibald, D., Hawkes, R. A., Schiphorst, C., Kelly, P., Grant, L., \& Mutrie, N. (2017). The relationships between golf and health: a scoping review. British Journal of Sports Medicine, $51(1), 12-19$.

Noble, N., Paul, C., Turon, H., \& Oldmeadow, C. (2015). Which modifiable health risk behaviors are related? A systematic review of the clustering of smoking, nutrition, alcohol and physical activity ('SNAP') health risk factors. Preventive Medicine, 81, 16-41.

Novitskaya, A. (2017). Patriotism, sentiment, and male hysteria: Putin's masculinity politics and the persecution of non-heterosexual Russians. NORMA, 12(3-4), 302-318.

Peng, W., Occa, A., McFarlane, S. J., \& Morgan, S. E. (2019). A content analysis of the discussions about clinical trials on a cancer-dedicated online forum. Journal of Health Communication, 24(12), 912-922.

Piercy, K. L., Troiano, R. P., Ballard, R. M., Carlson, S. A., Fulton, J. E., Galuska, D. A., George, S. M., \& Olson, R. D. (2018). The physical activity guidelines for Americans. Jama, 320(19), 2020-2028.

Postman, N. (1987). Amusing ourselves to death. London: Methuen.

Redmond, S. (2019). Celebrity. New York: Routledge.

Restuccia, A. (2018). Kavanaugh's drinking spotlights Trump's 'abnormal' abstinence. Politico. https://www. politico.com/story/2018/10/02/trump-kavanaugh-drinking-863144.

Ritchie, J., Lewis, J., McNaughton, C. N., \& Ormston, R. (2013). Qualitative research practice: a guide for social science students and researchers. Thousand Oaks: Sage.

Rowley, A. (2019). Putin Kitsch in America. Canada: McGill-Queen's University Press.

Samuel-Azran, T., Yarchi, M., \& Wolfsfeld, G. (2018). Rhetoric styles and political affiliations during Israel's 2013 “Facebook Elections". International Journal of Politics, Culture, and Society, 31(1), 15-30.

Shen, M. J., \& LaBouff, J. P. (2016). More than political ideology: subtle racial prejudice as a predictor of opposition to universal health care among US citizens. Journal of Social and Political Psychology, 4(2), 493-520.

Shomron, B., \& Schejter, A. (2020). Diversity in broadcasting as an enabler of capabilities: the case of Palestinian-Israeli women on public and commercial radio and television. Feminist Media Studies, 1-19,. https://doi.org/10.1080/14680777.2020.1804978

Skillen, D. (2016). Freedom of speech in Russia: politics and media from Gorbachev to Putin. London: Routledge.

Sokhey, S. W. (2020). What does Putin promise Russians? Russia's authoritarian social policy. Orbis, 64(3), $390-402$.

Stever, G. (2018). The psychology of celebrity. New York: Routledge.

Street, J. (2004). Celebrity politicians: popular culture and political representation. The British Journal of Politics and International Relations, 6, 435-452.

Street, J. (2012). Do celebrity politics and celebrity politicians matter? The British Journal of Politics and International Relations, 14(3), 346-356.

Street, J. (2019). What is Donald Trump? Forms of 'celebrity' in celebrity politics. Political Studies Review, $17(1), 3-13$.

Talshir, G. (2015). The new Israelis: from social protect to political parties. In M. Shamir (Ed.), The elections in Israel 2013 (pp. 31-58). New Brunswick \& London: Transaction Publication.

Tamul, D. J., Ivory, A. H., Hotter, J., \& Wolf, J. (2020). All the President's tweets: effects of exposure to Trump's "Fake News" accusations on perceptions of journalists, news stories, and issue evaluation. Mass Communication and Society, 23(3), 301-330.

Tempest, R. (2016). The charismatic body politics of President Putin. Journal of Political Marketing, 15(2-3), 101-119. 
Tetteh, D. A. (2019). Visibility of the ovaries and breasts: an analysis of Angelina Jolie's medical announcements. Feminist Media Studies, 19(5), 651-666.

Treisman, D. (2011). Presidential popularity in a hybrid regime: Russia under Yeltsin and Putin. American Journal of Political Science, 55(3), 590-609.

Turner, G. (2004). Understanding celebrity. London: SAGE.

Von-Sikorski, C., \& Herbst, C. (2020). Not practicing what they preached! Exploring negative spillover effects of news about ex-politicians' hypocrisy on party attitudes, voting intentions, and political trust. Media Psychology, 23(3), 436-460.

Vorberg, L., \& Zeitler, A. (2019). 'This is (not) entertainment!': media constructions of political scandal discourses in the 2016 US presidential election. Media, Culture and Society, 41(4), 417-432.

Vos, D., \& Van Aelst, P. (2018). Does the political system determine media visibility of politicians? A comparative analysis of political functions in the news in sixteen countries. Political Communication, 35(3), 371-392.

Wells, C., Zhang, Y., Lukito, J., \& Pevehouse, J. C. (2020). Modeling the formation of attentive publics in social media: the case of Donald Trump. Mass Communication and Society, 23(2), 181-205.

West, D., \& Orman, J. (2003). Celebrity politics. Upper Saddle River NJ: Prentice Hall.

Wheeler, M. C. (2013). Celebrity politics: image and identity in contemporary political communications. Cambridge: Polity Press.

Williamson, M. (2016). Celebrity: capitalism and the making of fame. Cambridge: Polity Press.

World Health Organization (2020) Coronavirus. https://www.who.int/health-topics/coronavirus. Accessed 7 Oct 2020.

Wright, L. A. (2020). Star power: American democracy in the age of the celebrity candidate. New York: Routledge.

Young, S., \& Bluth, R. (2020). Terrible role-modeling: how California lawmakers flouted pandemic safety practices. Los Angeles Times. https://www.latimes.com/california/story/2020-09-12/terrible-role-modelinghow-california-lawmakers-flouted-pandemic-safety-practices. Accessed 7 Oct 2020.

Zaman, J. A. (2018). The enduring value of the physical examination. Medical Clinics, 102(3), 417-423.

Publisher's Note Springer Nature remains neutral with regard to jurisdictional claims in published maps and institutional affiliations. 